\title{
7. The Radicalization of Cahiers: 1963-1969
}

\begin{abstract}
This chapter gives an account of the political radicalization of Cahiers du cinéma between the years 1963 (when Éric Rohmer was ousted as editor-in-chief and replaced by Jacques Rivette) and 1969 (when "Cinéma/ Idéologie/Critique" was published). Whereas in the 1950s, Cahiers had been studiously eclectic in its political leanings, under Rohmer it veered towards the far right. Rivette's editorship saw a corrective to this course, a tendency that was escalated when Comolli succeeded him in 1965 . The left-wing orientation in the second half of the 196os witnessed Cahiers' participation in a number of key battles: from the censorship of La Réligieuse to the sacking of Henri Langlois as head of the cinémathèque and the national upheaval of May'68, which affected the cinema as much as it did the rest of French daily life. At the same time, a younger crop of critics - including Serge Daney, Bernard Eisenschitz, Sylvie Pierre and Jacques Aumont-gravitated towards Cahiers during these years.
\end{abstract}

Keywords: Cahiers du cinéma, May '68, Cinémathèque française, Étatsgénéraux du cinéma, militant filmmaking

\section{From Rohmer to Comolli: Political Transformations in the 196os}

Cahiers has never been an apolitical publication. Even if it avoided any official declarations on political matters, such questions nonetheless left an imprint on the journal throughout the 1950s, a time marked by the Cold War, decolonization and political unrest in France. Conceived by its founders Bazin and Doniol-Valcroze as a broad church, Cahiers nonetheless shifted perceptibly to the right after the former's death in 1958. Rohmer's stewardship in the late 1950 s and early 1960 s saw the ascendancy of the macmahonien group within the journal. Named after the $8^{\text {th }}$ arrondissement

Fairfax, D., The Red Years of Cahiers du Cinéma (1968-1973). Volume I: Ideology and Politics. Amsterdam: Amsterdam University Press, 2021 DOI 10.5117/9789463728508_CHo7 
movie theater programmed by Pierre Rissient, the macmahoniens promoted a cinema of "transparent mise en scène" — as embodied in the work of the "four aces" of Walsh, Lang, Losey and Preminger — — while also associating with right-wing groupings, including neo-fascist organizations and Algérie française supporters. Such political allegiances occasionally surfaced in articles for Cahiers, including, notoriously, Michel Mourlet's "Apologie de la violence," in which the "Boileau of the macmahoniens" argued that "mise en scène in its truest essence tends [...] towards what certain people call 'fascism."'3 Proclamations such as this scandalized the leftist wing of Cahiers at the time - a faction that included Rivette, Doniol-Valcroze and Pierre Kast - and would eventually bring about the putsch against Rohmer. It should be remembered, however, that in spite of his conservative views, le grand Momo, as he was affectionately known, was even-handed enough to promote the writing of figures from across the political spectrum. Rohmer's tenure, for instance, saw a special issue on Bertolt Brecht put together by Bernard Dort as well as several articles by the PCF-aligned critic Georges Sadoul on Soviet cinema.

But this was not enough to prevent Rohmer from being ousted as editor-ofchief in the summer of 1963 . The move was presented to Cahiers' readership as a purely administrative measure: an editorial notice in the July 1963 issue, the first under the new regime, insisted that "it is only a matter of a modification in the structure and internal organization of our team" and that "Cahiers du cinéma is changing neither its line nor its orientation." A rider to the effect that "in addition to its original role as an organ of culture and information, it must once again become an instrument of combat" does point, however, to the pronounced shift in orientation the journal would subsequently undertake. ${ }^{4}$ The macmahoniens were no longer published, while other figures who sympathized with Rohmer (such as Jean Douchet and Barbet Schroeder) also left. The new orientation was most readily visible

1 Comolli has recently made the point that the "transparent" mise en scène advocated by the macmahoniens was "not overly characteristic of the style of these filmmakers, with the exception of some of Walsh's films." Comolli, Cinéma contre spectacle, p. 22 [p. 61]. Aside from Walsh, too, the "four aces" are associated with a left-liberal, anti-fascist political orientation totally at odds with the inclinations of the Rissient circle.

2 According to de Baecque, this was Mourlet's nickname within French cinephile circles, in reference to the seventeenth-century literary critic Nicolas Boileau-Despréaux. De Baecque, Histoire d'une revue vol II, p. 63.

3 Michel Mourlet, “Apologie de la violence," Cahiers du cinéma no. 107 (May 1960), pp. 24-27. For Mourlet's writings on the cinema, see Michel Mourlet, Sur un art ignoré: La mise en scène comme langage (Paris: Ramsay, 2008).

4 “Éditorial," Cahiers du cinéma no. 145 (July 1963), p. 1. 
in the series of interviews Rivette arranged with high-profile representatives of "cultural modernism": Roland Barthes, Claude Lévi-Strauss and Pierre Boulez. Although these encounters had mixed results, they provided the impetus to align Cahiers with contemporary trends in art and theory and move it away from the conservative classicism of Rohmer. ${ }^{5}$ Young critics gravitating around the review at this time included not only Narboni, Comolli and Jean-André Fieschi (dubbed the "gang of Corsicans" due to their last names, although only Fieschi was actually from the island) but also Jacques Bontemps, Jean Eustache, André Téchiné, Jean-Claude Biette, Louis Skorecki (writing as Jean-Louis Noames) and Paul Vecchiali. They were all sympathetic to the left and to the new generation of filmmakers and followed Rivette's signal to develop a much more political approach to their writing. The journal, therefore, increasingly did come to resemble the "instrument of combat" promised in 1963.

The other prominent transformation during this period came with the change of owner: in June 1964, Daniel Filipacchi, owner of the press conglomerate Union des Éditions Modernes, became majority shareholder in Cahiers' parent company, the Éditions de l'Étoile, and the journal's offices moved from the Champs-Elysées to 5 , rue Clément-Marot. ${ }^{6}$ Most spectacularly, the yellow-covered format of its first 14 years was abandoned for a larger, glossier, more modern layout. Doniol-Valcroze sought to soothe readers concerned about the ramifications of these changes with an editorial promising that "a change of address is not a change of doctrine" and insisting that despite the radical change in the "chassis," the "engine preserves the same principles." Indeed, the Cahiers team, with Comolli replacing Rivette as editor-in-chief the following year, would fiercely guard their editorial independence. This stance would color many of the disputes engaged in by the journal, which frequently placed Cahiers in conflict with its own proprietor.

Chief among these was the battle around Jacques Rivette's La Religieuse. In April 1966, the film became a rallying point for Cahiers when, with the backing of André Malraux, then the minister of culture under de Gaulle, its release was refused by the state censorship board. La Religieuse was not the first nouvelle vague film to be censored (Le Petit Soldat had been shelved in 1961), but the decision incensed the Cahiers editors, and the

5 These interviews will be discussed more deeply in Chapter 14.

6 De Baecque, Histoire d'une revue vol II, p. 96.

7 Jacques Doniol-Valcroze, "La ligne générale," Cahiers du cinéma no. 160 (November 1964), p. 7. In Doniol-Valcroze's metaphor, the "engine" contained "Ginibre-Rivette as the twin-bodied carburator, Comolli as the suspension, Delahaye as the exhaust pipe, Fieschi as the tires, Narboni as the brake discs, Bontemps as the radiator, Moullet as the sparkplug, etc." 
journal immediately mobilized in defense of Rivette's film. While Rivette himself remained relatively quiet during the campaign, the younger writers were joined by Godard and others in their vocal attacks on the Gaullist state. A vitriolic letter Godard wrote to the "minister of Kultur" was published in Le Nouvel Observateur on April 6 (and re-published in Cahiers). The filmmaker excoriated Malraux for having "cheerfully accepted the banning of a work which nevertheless taught you the exact meaning of two inseparable ideas: generosity and resistance," adding: "I see now that it was simply cowardice." ${ }^{8}$ In tandem with this text, Godard also took it upon himself to write the editorial for the April 1966 issue of Cahiers, which, if anything, was of even greater violence, accusing the Gaullist state of censoring Rivette's film out of political opportunism and claiming that the regime's "true, totalitarian face" had been revealed. ${ }^{9}$ This editorial itself caused a subsidiary mini-scandal: Filipacchi, incensed at the naked ferocity of Godard's language, refused to distribute the issue containing the text, even after it had come back from the printers. At a tremendous cost to his company, the original print run was pulped and a new issue was printed, identical to the former version save for a much less vituperative notice penned by the editors themselves. ${ }^{10}$ Over the next several months, meanwhile, La Religieuse would become a rallying cry for Cahiers against the repression wielded by a sclerotic Gaullist state, and the wave of solidarity with Rivette eventually succeeded in overturning the ban, with the film finding a release in September 1967 .

For the young Cahiers critics, this battle was something of a political dépucélage. But it also exemplified the politicized nature of showing films in a country groaning under rigid governmental and industrial censorship. Whereas Cahiers traditionally responded to films released on commercial runs in Parisian theaters, the journal was increasingly becoming interested in radical works encountered in international festivals that were unable to find distribution in France. At the same time as supporting parallel

8 See Jean-Luc Godard, “Lettre au Ministre de 'Kultur," Le Nouvel Observateur, April 6, 1966. Translated as "Letter to the Minister of 'Kultur," in idem., Godard on Godard, trans. and ed. Tom Milne (New York: Da Capo Press, 1972), pp. 237-238, here p. 238. The letter was also published in Cahiers du cinéma no. 177 (April 1966), pp. 8-9.

9 Jean-Luc Godard (unsigned), "La guerre est commencée," Cahiers du cinéma no. 177 (April 1966), unpublished version.

10 The scandal and Godard's editorial are retrospectively discussed by the Cahiers editors in À voir absolument (si possible). The editorial was left unfinished and completed by Comolli. It now exists in a few "souvenir editions" kept by the editors themselves. Acknowledgements go to Jacques Bontemps for providing a copy of the original version of the issue withdrawn from publication. 
efforts such as the Hyères festival, the journal took the initiative to launch a "Semaine des Cahiers" in Paris. In April 1966, two theaters (the Napoleon and the Saint-Paul) were hired for a week to screen seven unreleased films from the "new cinemas," including Prima della rivoluzione by Bertolucci, Nichtversöhnt by Straub/Huillet and Rysopsis by Skolimowski. Close to 10,000 tickets were sold, exceeding even the most optimistic forecasts. Reporting on the event, a jubilant Comolli noted an "intimate satisfaction at having made things 'move,' at having confronted readers and friends with our own passions." ${ }^{11}$ What Narboni would later call an "intra-cinematic militancy"12 continued with follow-up events in October 1967 and October 1968 and foreshadowed a prolonged practice of public outreach by the journal throughout its politicized period. Beginning with the tumultuous events of 1968, this activity was increasingly combined with "extra-cinematic" political activity.

\section{Four Fledgling Critics: Daney, Eisenschitz, Pierre and Aumont}

It was during this time that members of the future team, beyond the more established duo of Comolli and Narboni, entered the ranks of Cahiers. Four of them-Serge Daney, Bernard Eisenschitz, Sylvie Pierre and Jacques Aumont - began to contribute articles between 1963 and 1967. The pathways that led them to the journal, however, differed markedly. As opposed to the solid team that formed after 1968, the group of writers contributing to the journal in the mid-196os was more diffuse, more dispersed, with collaborators contributing from Italy, the US, and even Japan. As Daney explains: "There was no editorial committee, and all the important decisions were made by one or two people. There were a lot of freelancers that might or might not be accepted from time to time, without feeling themselves to be part of a global point of view." ${ }^{13}$

Daney himself, however, felt destined to write for the journal, confessing that "the idea of working for another magazine simply never crossed my mind." ${ }^{14}$ In his writings and interviews, including the testimonial dialogue with Toubiana published in book form as Persévérance, Daney is voluble about his early years. His first encounter with Cahiers came in 1959 when he

11 Jean-Louis Comolli, “Une semaine comme une autre," Cahiers du cinéma no. 178 (May 1966), p. 66.

12 Interview with Jean Narboni, March 18, 2014.

13 Daney, “Les Cahiers du cinéma 1968-1977: Entretien avec Serge Daney," p. 18 [p. 19 ].

14 Daney, La Rampe, p. 11. 
purchased issue no. 99 (which featured a dossier on Fritz Lang), and within five years, at the age of 20 , he began contributing to the journal. ${ }^{15}$ Born on June 4, 1944, Daney was raised by a single mother in the $11^{\text {th }}$ arrondissement, where he would live his entire life. Together, the two assiduously attended the neighborhood cinema located across the street from their apartment, the Cyrano-Roquette. Daney would later find out that his Jewish father, a bit-part actor by the name of Pierre Smolensky, had perished in the camps. ${ }^{16}$ This link between his parents and the cinema would lead Daney to later term himself a "ciné-fils," a concept whose autobiographical core will be further explored in Chapter 2o. Schooled at the Lycée Voltaire, where he found a mentor in the film scholar Henri Agel, Daney formed a close bond with Louis Skorecki, beginning a collaboration which would last until their years together at Libération in the $1980 \mathrm{~s} .{ }^{17}$ The two young cinephiles founded the ephemeral journal Visages du cinéma in 1962, declaring in the inaugural editorial "What we propose here is not so much an informative magazine, but rather an approach, a constant interrogation of those who make the true cinema. ${ }^{18}$ Despite only lasting two issues, Visages du cinéma is now a precious document of the duo's cinematic predilections. The first number, dedicated to Hawks, featured articles by Daney on Scarface and Rio Bravo, and by Skorecki on Hatari, as well as a piece by Agel on "The Modernity of Howard Hawks," who presumably wrote for the magazine at Daney's urging. The second, dated March 1963, turned its focus to the films of Preminger. ${ }^{19}$ This "gerontophilic" inclination, as Daney termed it, ${ }^{20}$ prompted him to travel with Skorecki to Los Angeles in 1964 and interview the old masters of classical Hollywood, who tended to treat the pair as "two oddballs, two amateurs, the fat one and the skinny one, at once petrified in admiration and determined not to be disappointed." ${ }^{21}$ All the same, the resulting interviews, with Sirk, Lewis, Hawks, McCarey, Sternberg and Fuller, were gratefully snapped up by Cahiers and served to "pay for their entry ticket" into the journal. ${ }^{22}$ Reviews of films including Family Jewels, Chimes at Midnight, La Prise de pouvoir par Louis XIV and Hurry Sundown

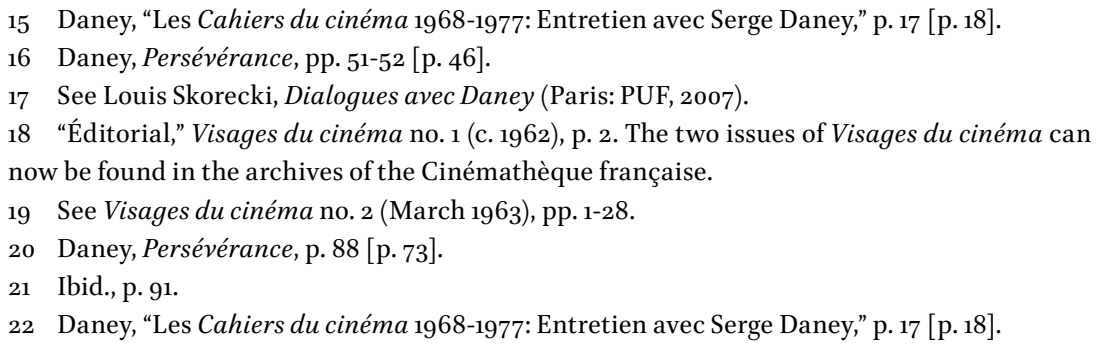
now be found in the archives of the Cinémathèque française.

19 See Visages du cinéma no. 2 (March 1963), pp. 1-28. 
followed, ${ }^{23}$ but Daney's independent streak and taste for international travel meant that he did not become a fully integrated member of the editorial team until around 1969-1970.

Eisenschitz shared with Daney a grisly autobiographical trait: his father, a half-Jewish Resistance fighter, was arrested and killed in the camps during World War II. In fact, Eisenschitz himself was born in a deportation facility in Calais on July 3, $1944 \cdot{ }^{24}$ His mother's side of the family consisted of Austrian Jewish intellectuals, and his maternal grandfather was the prominent painter Willy Eisenschitz. Educated at the elite Lycée Henri IV, where he was taught by the critic Jean-Louis Bory, Eisenschitz began attending the Cinémathèque in 1959, but his cinephilia departed markedly from the Cahiers canon, as he took an initial interest in the Hollywood B-movies screening at the Nickel Odéon cinema, as well as the Italian pulp cinema of the 1960s. ${ }^{25}$ In contrast with Daney's predestined fidelity to Cahiers, Eisenschitz was something of a critical polygamist, contributing to a number of magazines before settling with Comolli/Narboni's journal in 1968. A specialist in the art of compiling comprehensive filmographies (thus showing early signs of his skills as a film historian), Eisenschitz helped with dossiers on Billy Wilder in 1962 and the special issue on American cinema in 1963 but would not write his first article for Cahiers until November 1966, with a report on the shoot of Losey's Accident. ${ }^{26}$ In the meantime he collaborated on issues of L'Avant-scène cinéma and the right-leaning Présence du cinéma (which was edited by Mourlet after he left Cahiers) and wrote intermittently for Midi-minuitfantastique, where he discussed the work of Bava, Cottafavi and Petri, among others. ${ }^{27}$ Eisenschitz is even one of the few

23 See Serge Daney, "Un rien sur fond de musique douce (Family Jewels)," Cahiers du cinéma no. 175 (February 1966), pp. 36-37; "Welles au pouvoir (Falstaff)," Cahiers du cinéma no. 181 (August 1966), pp. 26-28; "Le pouvoir en miettes (La Prise du pouvoir par Louis XIV)," Cahiers du cinéma no. 186 (January 1967), pp. 64-65; and "La dé-faite (Hurry Sundown)," Cahiers du cinéma no. 196 (December 1967), pp. 63-64.

24 For more on Eisenschitz' family background, including his links with Willy Eisenschitz, see Eisenschitz Bernard, dir. Georges Ulmann, 2013.

25 Bernard Eisenschitz, interviewed by Fernando Ganzo, "A French Roman. A Story about the Influence of Soviet Avant-Garde on Cahiers du Cinéma and the Later Rediscovery of Nicholas Ray: An Interview with Bernard Eisenschitz," Cinema Comparat/ive Cinema no. 2 (Spring 2013), pp. 18-28, here p. 19.

26 Bernard Eisenschitz, “Joseph Losey sur 'Accident,"” Cahiers du cinéma no. 184 (November 1966), pp.12-13. According to Eisenschitz, he also conducted an extensive interview with Cy Endfield which was rejected by the editorial team and never returned. Interview with Bernard Eisenschitz, April 1, 2014.

27 Eisenschitz's contributions to Midi-minuit fantastique were: "Les trois derniers films de Mario Bava," Midi-minuit fantastique no. 8 (January 1964), pp. 62-63; "Lettre d'Italie," Midi-minuit 
writers to have published with both Positif and Cahiers, covering the 1967 Pesaro film festival as well as conducting interviews with Roger Corman and Abraham Polonsky for the former journal. ${ }^{28}$ This brief affiliation would not prevent him from lacerating Positif in an April 1969 notice, deriding its "outrageous self-satisfaction, with a taste for the pompous platitude, and its corollary, contempt for the outside world." ${ }^{29}$ Eisenschitz's articles for Cahiers, even once he became an established member of the editorial committee, were mostly restricted to short critical notices, but his true value to the group came with the meticulous preparatory work carried out for the two dossiers on 1920 Soviet cinema in 1970, for which he traveled to Moscow in 1969. His talents as a historian, moreover, were in evidence in the long-form texts he wrote in the late 196os, a body of work that includes special issues of L'Anthologie du cinéma on Ernst Lubitsch (March 1967) and Douglas Fairbanks (December 1969),,$^{30}$ and a 1967 monograph dedicated to Humphrey Bogart, which comprised a biographical overview penned by Eisenschitz, testimonies from those who worked with "Bogie," and a detailed filmography. With their concern for factual precision and historiographical rigor, all three works can be seen as methodological precursors to the later studies Eisenschitz composed on figures such as Fritz Lang and Nicholas Ray, and this approach is already consciously defended in the introduction to Bogart:

Hence our meticulous and obsessive interest for figures, dates and titlesequences, which is so often mocked; one should not point out their uselessness, since the filmography (to only take one example) represents, for anyone who looks at it honestly, a renewal of the perspective on Bogart admitted until now, in that it re-establishes the true value of the role played by Warner Bros and its conceptions of film production in the career and life of the actor in question. ${ }^{1}$

fantastique no. 9 (July 1964), pp. 40-42; "Entretien avec Edgar G. Ulmer" (with Jean-Claude Romer), Midi-minuit fantastique no. 13 (November 1965), pp. 1-14; "Cannes 65," Midi-minuit fantastique no. 13 (November 1965), pp. 37-50; and "Lettre d'Italie," Midi-minuit fantastique no. 13 (November 1965), pp. 55-58.

28 See Bernard Eisenschitz, Bertrand Tavernier and Chris Wicking, "Corman parle," Positif no. 59 (March 1964), pp. 15-28; Bernard Eisenschitz, "Abraham Polonsky par lui même," Positif no. 84 (May 1967), pp. 7-18; and Bernard Eisenschitz, Bernard Cohn and T. Perez-Turrent, "Pesaro 1967," Positif no. 88 (October 1967), pp. 20-26.

29 Bernard Eisenschitz, "Le cahier des autres," pp. 58-59.

30 See Bernard Eisenschitz, "Lubitsch," L'Anthologie du cinéma no. 23 (March 1967); and Bernard Eisenschitz, "Fairbanks," L'Anthologie du cinéma no. 59 (December 1969).

31 Bernard Eisenschitz, Bogart (Paris: Losfeld, 1967), p. 10. 
The accession of Sylvie Pierre and Jacques Aumont to the Cahiers team was far more straightforward than that of Eisenschitz or Daney. Moreover, their passages were inextricably linked, as the two were married between 1965 and 1971, after first meeting in $1962 .{ }^{32}$ Having moved in the same friendship circles as the Cahiers writers for several years, they both began publishing articles in 1967 and quickly became central figures in the editorial team. Pierre was the first to feature in the journal. Raised in a middle-class family (an engineer father, a schoolteacher mother) in the same neighborhood as Serge Daney, Pierre was also born within a month of him, on July 22, 1944, although the two only became properly acquainted with Daney's return to France in 1970. Her early experiences of the cinema were mainly of the "Saturday night movie" variety, although a screening of Paisà at the age of 12-13 remains a vivid memory.33 Taking preparatory classes for the École normale supérieure, she paid for her studies by writing for the Filipacchiowned teen-oriented magazine Mademoiselle âge tendre. It was in their common offices that she met the Cahiers editors and began frequenting the Cinémathèque with them from 1964 onwards. At their encouragement, Pierre submitted an article on Jancsó's The Round-Up, for which she recalls having made "a tremendous effort - I would have been humiliated if they had refused my first text."34

The review was published in February 1967. Pierre thus became the first woman to penetrate a hitherto purely masculine grouping. ${ }^{35}$ She is often self-deprecating about her status as the first female writer for Cahiers, saying "I was a very pretty girl, and since they were very macho, very seductive, very dandyish, seeing a smart, pretty girl write for them was amusing. They forgave me for being an intellectual because I was cute." ${ }^{36}$ More seriously, however, she has also claimed that she was "subtly patronized" by her male colleagues. ${ }^{37}$ Certainly, Pierre rarely pursued an explicitly feminist agenda on the pages of the journal - this would have to wait until the 1970s, with the contributions of writers such as Thérèse Giraud, Dominique Villain, Danièle Dubroux and Nathalie Heinich. The

32 Interview with Sylvie Pierre, March 7, 2014.

33 See Sylvie Pierre, "À mes parents," Trafic no. 17 (Winter 1996), pp. 77-87.

34 Interview with Sylvie Pierre, March 7, 2014.

35 Sylvie Pierre, "L’ordre et l'ordinateur (Les Sans-espoir)," Cahiers du cinéma no. 187 (February 1967), pp. 66-68.

36 Ibid.

37 Sylvie Pierre, interviewed by Bill Krohn, "Interview with Sylvie Pierre," Senses of Cinema no. 23 (December 2002), sensesofcinema.com/2002/feature-articles/pierre/ (accessed January 1, 2021). 
upside of this treatment, however, was that Pierre subjected herself to a grueling critical apprenticeship in order to catch up with the accrued cinephilic knowledge of her Cahiers colleagues. On top of writing texts on Eustache, Guerra and Rouch, as well as an in-depth piece on the "considerable talent" of G.W. Pabst, she also assumed responsibility for the journal's photothèque after the tragic drowning of Jean-Pierre Biesse in July $1967 \cdot 3^{8}$ From that point on, she would play a central role in Cahiers' editorial work.

Joining his then wife as a Cahiers contributor, Aumont published his first batch of articles in the October 1967 issue. Pride of place here was his review of La Religieuse (an inordinate honor for a critical debutant) in which he poetically claimed that "the cinema—art—is, therefore, not that which lays mysteries bear, but that which poses them in the density of their obscurity. It is what lets us see the night." ${ }^{39}$ Born into an aristocratic Lyonnais family on February 25, 1942, Aumont completed his studies at the École polytechnique (an institution known for educating France's business elites) and upon graduating in 1965 obtained a position as an engineer at the ORTF, the French public television station, which he held until going full-time with Cahiers in $1970 .{ }^{40}$ Soon, however, he found himself more interested in attending the thrice-daily Cinémathèque screenings with Pierre and the Cahiers editors. Aumont's cinematic tastes underwent a notable metamorphosis in this time: "I did not read Cahiers before meeting [the journal's editors]. I read Positif. I adored John Huston... I switched camps because I was easily influenced, and because speaking with Narboni was spellbinding. His arguments were both very rational and totally seductive, nobody could resist him."41 Like Pierre, Aumont also assumed a significant administrative role in the journal: "Because I had gone to the Polytechnique," he acerbically explained, "they thought I could count up to twelve without making a mistake. So, in 1970, I was confided with the administration of the Éditions de l'Étoile, the

38 See Sylvie Pierre, "Une œuvre de salut public (Le Père Noël a les yeux bleus)," Cahiers du cinéma no. 188 (March 1967), p. 59; "Poétique et politique (Oz fusis)," Cahiers du cinéma no. 190 (May 1967), p. 66; "Le regard brûlant du conteur (La chasse au lion à l'arc)," Cahiers du cinéma no. 192 (July-August 1967), pp. 65-66; and "Le considérable talent de G.W. Pabst," Cahiers du cinéma no. 193 (September 1967), pp. 42-47. A tribute to Biesse was published in Cahiers $d u$ cinéma no. 193 (September 1967), p. 5 .

39 Jacques Aumont, "Voir la nuit (La Religieuse)," Cahiers du cinéma 194 (October 1967), pp. 64-65. 40 Aumont was also briefly a member of the Jeunesse communiste (the youth wing of the PCF) in 1963 but was never involved in the organization in a serious way. See Interview with Jacques Aumont, March 11, 2014.

41 Jacques Aumont, interviewed by Patrice Blouin and Jean-Marc Lalanne, "Le gai savoir," Les Inrockuptibles, April 27, 2005, pp. 36-38, here p. 37. 
publisher of Cahiers." ${ }^{\text {22 }}$ With texts on Godard, Skolimowski, Satyajit Ray and Jancsó, among others, Aumont published prolifically during his first years at Cahiers, and his writing already attests to the conceptual logic and trenchant intelligence of his more mature works of film theory. Nonetheless, only a handful of his texts from this period-notably, "Le caractère inépuisable du murmure" from September 1968 and "Le concept de montage" from April 1969-offered a prolonged reflection on the cinema of the sort that he would later produce, and today he tends to downplay the importance of his experience in the journal for his subsequent career. In the end, more than his individually authored texts, it is Aumont's contribution to the journal's collective endeavors - the texts on Young Mr. Lincoln, New Babylon, Morocco and Ice, and, above all, the mammoth Eisenstein translation project - that constitute the most crucial aspect of his involvement with Cahiers.

\section{On the Barricades: Cahiers in 1968}

In the late 196os, it was customary for Cahiers to include an epigram from a literary or cultural figure at the top of its contents page, inside the front cover. In March 1968, Lenin received the honor, with the journal reproducing his statement from a 1919 lecture at the Sverdlov University that "We must consign the state-machine to the scrap-heap." 43 The quote was an augury of the fact that 1968 for Cahiers - as with the rest of France and a significant part of the world - would be a year of revolt. The year began with the sacking of Henri Langlois from the Cinémathèque in February, leading to a dogged and ultimately victorious protest movement against state interference in the archival institution, climaxed with the uprising of May, and continued with a spirit of radical struggle that permeated the journal. Although Cahiers' process of politicization predates the social explosion of 1968, the editors' central involvement in these seismic events transformed the nature of the journal, paving the way for their own existential dispute with Filipacchi the following year.

Langlois' dismissal as head of the Cinémathèque française on February 9, 1968 was foreseeable: despite having overseen the organization since founding

42 Jacques Aumont, interviewed by Nicole Vulser, “Jacques Aumont, le cinéma né sous X," Le Monde, September 29, 2003.

43 Cahiers du cinéma no. 198 (March 1968), p. 3. For the original source, see V.I. Lenin, "The State: A Lecture Delivered at the Sverdlov University, July 11, 1919," The Collected Works of V.I. Lenin vol. XXIX (Moscow: Progress Publishers, 1976), pp. 470-488. 
it in the 1930s, his idiosyncratic managerial style met with resistance from the technocratic functionaries of a sclerotic state apparatus, galled by the significant public subsidies handed out for its film preservation activities. It nonetheless came as a shock when, at a meeting of the Cinémathèque's administrative board, its government-appointed chairman Pierre Moinot proposed that Langlois, his three-year contract having expired, be replaced by Pierre Barbin, thus placing the Cinémathèque under the direct control of the state film body, the Centre National du Cinéma (CNC). With the government-aligned members forming a 16-8 majority on the board, the pro-Langlois minority walked out of the meeting and the motion was carried. ${ }^{44}$ That the dismissal was a "remote-controlled maneuver, resembling a putsch in every way" was made clear, in the eyes of Cahiers at least, by the fact that, the same afternoon, Barbin moved into Langlois' offices, evicting its employees (including Mary Meerson and Marie Epstein) and changing the locks on its doors. ${ }^{45}$ The next day, the Cahiers bureau became an unofficial headquarters for the movement to reinstate Langlois, and the journal's editors began the process of contacting filmmakers to withdraw authorization for their films to be shown at the Cinémathèque, in solidarity with its ousted supremo. Combined with a rolling picket of the Trocadéro auditorium, this effectively stopped screenings from taking place. The "Children of the Cinémathèque" disseminated leaflets declaring that "the Cinémathèque will never open without Henri Langlois." ${ }^{26} \mathrm{~A}$ demonstration on February 14 of 3000 "friends of Langlois" calling for the resignation of Barbin was violently attacked by the police. The scenes of bruised and bloodied filmmakers (Godard had his trademark dark glasses smashed during a scuffle) have led many to see the Langlois movement as a prologue to May '68, a claim made by Cahiers itself as early as June that year. ${ }^{47} \mathrm{On}$ the Friday, an incendiary press conference featuring Godard, Rivette, Chabrol, Renoir, Rouch, Kast, Astruc, Carné and others was held, in which Rivette praised Langlois' Cinémathèque as being "not like a museum but like a permanent action, a permanent revolution, [...] a permanent discovery of what is justly

44 Issue no. 199 of Cahiers includes a precious timeline of the "Affaire Langlois" which, while evidently partisan in its pro-Langlois sympathies and violent condemnation of the state, nonetheless allows us to establish a precise chronology of the events surrounding the dismissal. See Jean-Louis Comolli, “L'Affaire Langlois: 1. Historique et bilan,” Cahiers du cinéma no. 199 (March 1968), pp. 32-33.

45 Ibid.

46 "Declaration des Enfants de la Cinémathèque française," in the Fonds Comité de Défense de la Cinémathèque française, Espace chercheurs de la Cinémathèque française, dossier CDCF9-B1. 47 "Le retour de Langlois," Cahiers du cinéma no. 202 (June-July 1968), p. 68. 
the permanence of the cinema., ${ }^{m 8}$ The same day, a "Comité de Défense de la Cinémathèque française" was formed, with Alain Resnais elected as its president. As with the storm over La Religieuse, Malraux was a prominent target, with Godard stating, "as if by chance it is always the same André Malraux who eliminates those who speak a certain language and have a certain independence. ${ }^{\text {49 }}$ By February 23, hundreds of filmmakers and other cultural figures had signed the petition in support of Langlois, and even Jack Valenti, president of the Motion Picture Association of America, had given his backing to the "dragon of the Cinémathèque. $5^{0}$ The state's position became increasingly untenable - de Gaulle himself was heard to grumble "Who is this Henri Langlois?" ${ }^{1}$ On behalf of the regime, Barbin engaged in a counter-propaganda campaign, which was denounced by Comolli in the newspaper Combat..$^{2}$ Eventually, on April 22 (75 days after his dismissal) the government ceded to the pressure and allowed Langlois to return to his former position. Cahiers, which featured Langlois on the front cover of its $200^{\text {th }}$ issue, trumpeted the victory as one where, "for the first time, perhaps, the cinema in its entirety, from cinephiles to filmmakers, [is] victorious (and not in the Pyrrhic sense, as is usually the case) against those who-agents of the state or not, perfidious or not-more or less engage in opposing it and weakening it." Its editors argued for "consider[ing] the battle of the Cinémathèque as the first of those, all of those, that are in the offing, and that must be won if the French cinema is able to conquer-after so many years of adolescence, crisis and oversight - its true status, a status warranted by its maturity and its liberty, the former real, the latter, alas, still virtual."53 The victory came at a price, however, as all state subsidies for the archive were henceforth removed. As the third and final issue of the L'Affaire Langlois bulletin put it, the Cinémathèque now found itself "free but poor." 54

48 "L'Affaire Langlois: 2. Conférence de presse," Cahiers du cinéma no. 199 (March 1968), pp. 34-44, here p. 37.

49 Ibid., p. 43.

$5^{0}$ See Laurent Mannoni, Histoire de la Cinémathèque française (Paris: Gallimard, 2006), p. 390. Mannoni discusses the Langlois dismissal more generally on pp. 361-404.

51 See Colin MacCabe, Godard: A Portrait of the Artist at Seventy (New York: Farrar, Straus and Giroux, 2003), p. 202.

$5^{2}$ This material is reprinted in a "Brochure Barbin" disseminated by the Langlois Defense Committee. See Fonds Comité de Défense de la Cinématheque française, Espace chercheurs de la Cinémathèque française, $\mathrm{CDCF}_{13}-\mathrm{B}_{13}$. The riposte was originally published in the March 1 , 1968 issue of Combat.

53 "Éditorial," Cahiers du cinéma 200-201 (April-May 1968), p. 5.

54 L'Affaire Langlois no. 3 (May 18, 1968). Fonds Comité de Défense de la Cinémathèque française, dossier $\mathrm{CDCF}_{9}-\mathrm{B} 1$ 
The role of the Cinémathèque protests as a precursor to May'68 has often been overstated, and they rarely feature prominently in non-cinema-centric histories of the uprising. As Kast cautioned: "If it is impossible to cry 'Viva Castro' without crying 'Viva Langlois,' one can perfectly well shout 'Viva Langlois' without thinking 'Viva Castro.'"55 The timing of the two revolts is nonetheless uncanny. Within two weeks of Langlois' reinstatement, rolling student occupations at the Université de Nanterre on the western perimeter of Paris had spread to the Latin Quarter, culminating in the "night of the barricades" on May 10. A mass demonstration of up to 1 million protestors marched from République to Denfert-Rochereau on May 13, and by May 24, 10 million workers were on strike across France, bringing the country to a standstill and threatening to topple the government. This is not the place to delve deeply into the events of May '68, which have given rise to a vast literature in the five decades since they shook Europe. ${ }^{5}$ It should nonetheless be noted that the Cahiers editors were eager and active participants in the revolt. Comolli, who collaborated on a photo-essay of the events on the occasion of the $5^{0^{\text {th }}}$ anniversary of May, has confirmed that the members of the équipe were on the barricades at the Sorbonne and elsewhere in the Latin Quarter, ${ }^{57}$ while Narboni has stated: "In May we were entirely in the movement, from start to finish. There was no hesitation." ${ }^{8}$ As with the rest of the country, work at the journal essentially ceased for the month. Daney, still not entirely integrated into the editorial team, experienced the revolt "differently to the Cahiers folks (who were, I felt, rather reformist or 'reviso' as we used to say); in a radical, destabilizing, almost hippy-like manner."59 Instead of joining his fellow film critics, he spent the events with a "gang of anarcho-dandies" linked to Philippe Garrel. Participating in the occupation of the Odéon theater, he recalls being particularly influenced by Debord's Société du spectacle at the time, a treatise that, with its near totalizing

55 Pierre Kast, "A Farewell to the Movies," Cahiers du cinéma no. 200-201 (April-May 1968), pp. 13-18, here p. 18 .

$5^{6}$ For the wave of militant filmmaking produced during and after the events, see Sébastien Layerle, Caméras en lutte en Mai 68: "Par ailleurs le cinéma est une arme..."(Paris: Nouveau Monde, 2008); and Paul Grant, Cinéma Militant: Political Filmmaking \& May 1968 (New York: Wallflower Press, 2016). Grant makes the argument that this strand of cinema was an implicit, practical riposte to the theoretical excesses of "apparatus theory" as developed by Tel Quel and Cahiers. 57 Comolli, "Yes, we were utopians (Part 1)." See also Jean-Louis Comolli and Jacques Kebadian, Les fantômes de Mai 68 (Crisnée: Yellow Now, 2018).

$5^{8}$ Interview with Jean Narboni, March 18, 2014.

59 See Daney, Persévérance, pp. 97-99 [pp. 80-82]. Here, Daney noted the irony of his participation in the occupation of the Odéon theater, when he had always felt that the theater as an art form was not "home" but a "place of unease." 
denunciation of the culture industry, was distinct from Cahiers' political/ theoretical framework. ${ }^{60}$ Delahaye, meanwhile, found himself on the south coast during the uprising, covering Cannes for Cahiers, and reported on the cancelation of the festival after vivid protests led by Godard and Truffaut had succeeded in interrupting the May 18 gala screening of Carlos Saura's Peppermint Frappé. ${ }^{61}$

The key activity for Cahiers during this volatile period, however, was its participation in the États-généraux du cinéma (EGC), a series of mass meetings attracting approximately 1500 members of the French film industry to the École Louis Lumière (a filmmaking school) on the Rue Vaugirard. The États-généraux - the name was a deliberate nod to France's revolutionary heritage - continued the militant, all-embracing spirit of the pro-Langlois movement and promptly declared the abolition of the CNC. ${ }^{62}$ Due to the general strike, no filmmaking or projection took place on French soil, with the exception of militant films linked directly to the protest movement. Interrogating the organizational principles of the French film industry was evidently in the air-Cahiers had only just published their dossier "Vers un livre blanc du cinéma français," which consisted of a questionnaire about the functioning of the CNC filled out by 28 French filmmakers, from Philippe Garrel to Jacques Tati. ${ }^{63}$ As such, most of the EGC's energies were spent in drawing up plans for the revolutionary reconstruction of the economic and cultural basis of the cinema. Nineteen projects in all were developed, of which four gained significant support. The project most closely

60 See Guy Debord, La Société du spectacle (Paris: Buchet/Chastel, 1967). Translated as The Society of the Spectacle, trans. Donald Nicholson-Smith (New York: Zone Books, 1995). In his later writings, Comolli nonetheless evinces a profound debt to Debord.

61 Michel Delahaye, "Fin d'un festival: Cannes," Cahiers du cinéma no. 203 (August 1968), pp. 26-27. The 1968 Cannes festival is discussed at greater length by Peter Cowie in Revolution!: The Explosion of World Cinema in the Sixties (New York: Faber and Faber, 2004), pp. 199-205. While Cahiers eagerly supported the cancelation of Cannes, it did not support a blanket boycott of all festivals and later in the year published a detailed position paper defending its participation at Venice, which, while undeniably a "bourgeois festival," proposed an "audacious," highly politicized program (including Straub, Kluge, Bertolucci, Pasolini and Sembene) judged to be useful in "the struggle for a renewal of the cinema." La Rédaction, "Venise malgré tout," Cahiers du cinéma no. 206 (November 1968), pp. 23-24. The editors did, however, urge a boycott of Venice in 1971, after the festival's organization had been taken over by right-wing forces. See "Venise," Cahiers du cinéma no. 232 (October 1971), pp. 57-58.

62 For an overview of the États-généraux written dans le chaud, see "Les états-généraux du cinéma," Cahiers du cinéma no. 203 (August 1968), pp. 23-46. The events are also discussed by Sylvia Harvey, May'68 and Film Culture, pp. 17-27.

63 "Vers un livre blanc du cinéma français," Cahiers du cinéma no. 200-201 (April-May 1968), pp. 73-93. 
associated with Cahiers - no. 16, dubbed "La Ligne générale (L'ancien et le nouveau)" - advocated the abolition of censorship bodies, a public sector of production and distribution freed of the profit motive and run on the principle of "autonomy and autogestion," and an end to the institutional division between cinema and television, with the EGC becoming the chief organizational body for the general direction of all audiovisual activities. Projects 13 (backed by technicians aligned with the Confédération générale du travail [CGT], France's communist-dominated confederation of trade unions) and 19 (endorsed by Michel Cournot, Claude Lelouch, Marcel Carné and others) offered variations on the same fundamental conception, and the second General Assembly saw a proposal synthesizing the three projects drawn up. This program nonetheless met with the dogged opposition of the supporters of project 4 (who included Marin Karmitz and Claude Chabrol), the most utopian of the proposals, which called for free entry to all screenings, and was seen by Cahiers' as "both a warhorse for the 'hardest' faction," and a "Trojan horse" that felled, one by one, all the other platforms. ${ }^{64}$. When no consensus could be reached, the third General Assembly on June 5 settled on a vague final motion elaborating the broad principles on which the new cinema was to be organized. As May became June, however, and De Gaulle re-established his grip on the nation with the calling of legislative elections for the end of the month, the revolutionary spirit of the EGC faded, and none of the plans elaborated at its meetings were realized. The CNC was soon restored, and commercial film production continued virtually unchanged from the way it functioned before May.

\section{From May '68 to "Cinéma/Idéologie/Critique": Becoming a Marxist Film Journal}

For Cahiers, by contrast, the events of May had a lasting, transformative effect, which led to Comolli/Narboni's open avowal of the Marxist orientation of the journal in October 1969. The texts of this transitional period attest to the buoyant mood felt among the Cahiers writers at the time. Not only were they faced with a cinema in effervescence, but the critics themselves were politically optimistic, confident that May 1968 was merely a dress rehearsal for the revolution to come. This insurrectionary atmosphere not only contaminated their dialogues with filmmakers and their critical writings, which became more and more exigent in their radicalism, it also 
led the editors to question the nature of Cahiers itself. Not yet seeking a political alignment with the PCF, the editors prized their sense of independence, but this increasingly ran counter to the journal's membership of the Filipacchi stable. In affirming their autonomy from Cahiers' owner, the editors saw fit both to modify the format of the journal and to heighten the political radicalism of its content. These changes were first made public in August 1968, when an editorial alerted readers to the "disappearance of the Council of Ten and the reduction of the number of critical notes in the 'List of Films Released in Exclusivity in Paris'," as well as further prospective changes to other sections linked with current events in film, which in the view of the editors "corresponded less and less to what constitutes presentday cinema for us." ${ }^{\prime 6}$ With political censorship and the commercial film market wielding deleterious effects, it was in fact the cinematic mainstream that had become "marginal" for Cahiers. The response to these steps was mixed-one reader proclaimed that "you are drowning in your aberrant communism"66 _ but two months later a new section appeared_-À voir absolument (si possible)"-listing new films recommended by Cahiers regardless of their release status. ${ }^{67}$

Of greater importance than these formal changes was the politicization of film criticism within the review in the years 1968 and 1969. As Comolli and Narboni acknowledged in October 1969, "fragmentarily, our position could already be read in recent texts (articles, editorials, debates, responses to readers' letters), but in a vague and accidental manner." ${ }^{68}$ To a large degree, this came about through encounters with filmmakers who had themselves radicalized in their views. Indeed, this period is particularly rich in interviews with politically engaged and formally experimental directors-including Rivette, Garrel, Borowczyk, Jancsó, Makaveyev, Polonsky, Perrault, Bene and Rocha - who outlined their thoughts on the relationship between art and revolutionary activism. Rivette, for instance, declared to his younger colleagues that "a revolutionary cinema can only be a 'differential'

65 "Éditorial," Cahiers du cinéma no. 203 (August 1968), p. 5. The "Council of Ten" was a grid of ratings (from zero to four stars) by ten Paris-based critics enlisted by Cahiers. It was later revived and continues to be published to this day.

66 See Jacques Aumont, "Le cahier des lecteurs," Cahiers du cinéma no. 205 (October 1968), p. 10. A few months later, Narboni defended the changes and noted the support of other readers for Cahiers' transformation. See Jean Narboni, "Le cahier des lecteurs," Cahiers du cinéma no. 208 (January 1969), p. 5 .

67 The rubric lasted little more than a year, appearing for the final time in March 1970, the journal's first post-Filipacchi issue.

68 Comolli/Narboni, “Cinéma/idéologie/critique," p. 11 [p. 251]. 
cinema, which challenges the rest of the cinema," while "films that content themselves with taking the revolution as a subject actually subordinate themselves to bourgeois ideas of content, message and expression. ${ }^{\prime 69}$ Rivette mentioned Terra em transe as a favorable model for revolutionary film, and Rocha himself was interviewed for the July/August 1969 issue, where he put forth the view that "political film should not be accompanied by too much systematization" and indicated his preference for "polemical films, where everything is mobile," proceeding to express his fear that "systematization would break the creative élan, especially if this creation is initially chaotic or spontaneist." ${ }^{0}$

While there was a great deal of interest within the journal in the political documentaries of international filmmakers such as Fernando Solanas ( $L a$ Hora de los Hornos) and Emile de Antonio (In the Year of the Pig), militant filmmaking in France mostly left the Cahiers critics cold. As the "Cinema/ Ideology/Criticism" editorial had outlined, this mode of film production could be divided into two categories: the vast majority contented themselves with "depict[ing] miners' strikes in the same formal system as Les Grandes Familles" and thus failed to "truly differentiate themselves from non-political cinema., ${ }^{71}$ While an alternative approach would consist of films that "concentrate on the problem of representation in making the filmic material function," few works successfully managed to do this. $L a$ Reprise de travail aux usines Wonder was virtually the only French militant film made during the 1968 protests to find grace in the eyes of the Cahiers editors and was described by Rivette as "the only interesting film on the May 'events,' [...] because it is a terrifying and painful film." ${ }^{72}$ The Cahiers writers did not entirely refrain from critiquing right-wing productions: Comolli called Green Berets "rubbish" and Narboni later described L'Armée des ombres as "the first and finest cinematic example of Gaullist Art, in content and form." ${ }^{73}$ But the chief targets of their criticism in this period

69 Jacques Rivette, “Le temps déborde: Entretien avec Jacques Rivette," p. 19 [p. 33].

70 Glauber Rocha, interviewed by Michel Delahaye, Pierre Kast and Jean Narboni, "Entretien avec Glauber Rocha," Cahiers du cinéma no. 214 (July-August 1969), pp. 23-40, here pp. 26, 29. 71 Comolli/Narboni, “Cinéma/idéologie/critique," p.14 [p. 258]. Comolli has recently spoken of this cinema in the following terms: "We ferociously critiqued militant films at the time, which we did not like at all. By the way, I recently re-watched some of them in the DVD boxset put out by Éditions Montparnasse, and, unfortunately, they are woefully bad. Films such as Oser lutter, oservaincre are calamities, they are very bad films." See Comolli, "Yes, we were utopians (Part 1)."

72 Rivette, “Le temps déborde: Entretien avec Jacques Rivette," p. 20 [p. 35].

73 Jean-Louis Comolli, "Les berets verts," Cahiers du cinéma no. 215 (September 1969), p. 65; and Jean Narboni, “L'Armée des ombres," Cahiers du cinéma no. 216 (October 1969), p. 63. 
were films of the left that did not meet their exacting requirements for a break with the dominant "system of representation." These fictions de gauche, as they would later be called, gained in prominence in this period, as the film industry saw potential profits to be made in films with political themes but conventional narrative structures, and they will be discussed at greater length in Chapter 8.

Within Cahiers' ranks, the politicization of 1968 and 1969 was not without its human toll, as several critics departed from the journal. Jacques Bontemps, who played a key role in the years 1965-1967, ceased writing at the beginning of 1968 in order to concentrate on his philosophy studies at the École normale supérieure, but his departure was amiable. He still retains close ties with Pierre, Comolli and Narboni and has returned to film criticism in recent years with a string of articles for Trafic. ${ }^{74} \mathrm{Jean}$-Claude Biette had moved to Italy, where he occasionally filed reports on the local film scene, but after 1970 he took a hiatus from the journal that lasted until 1977, when he resumed writing criticism in tandem with a blossoming career as a filmmaker. ${ }^{75}$ Jean-André Fieschi's rupture with Cahiers was less benign. Finding himself in disagreement with the journal's "anti-authoritarian" politics during the May events, going so far as to tell Comolli during one of the last marches of May '68, "you are petty-bourgeois, we must participate in the movements, ${ }^{76}$ Fieschi quit the journal and joined the PCF, becoming one of the main film critics for La Nouvelle Critique. During Cahiers' rapprochement with the party, close ties would again be established with Fieschi (he participated in discussions on Othon and Ice), and the critic was to forge an enduring bond with Eisenschitz when the latter joined him at La Nouvelle Critique, but relations soured during Cahiers' Maoist period. Upon Fieschi's death in 2009, Comolli lamented that "of this friend from my first days in Paris I am left with a sense of regret. [...] The reader will understand how much this once close friendship with JAF counted for me. His death left me frightened."77

Still more acrimonious was the rift with Delahaye. A generation older than his colleagues (he was born in 1929) and from an impoverished rural background that contrasted with the bourgeois milieux of most of the other Cahiers writers, Delahaye also distinguished himself by refusing to accede

74 See, for instance, Jacques Bontemps, “Diligence des Straub," Trafic no. 9 (Winter 1994), pp. $76-85$.

75 Biette was particularly close to Daney and would later join him as an editor at Trafic.

76 Comolli, "Yes, were utopians (Part 1)."

77 Comolli, Corps et cadre, pp. 478-479. 
to the Marxism of his fellow critics, retaining an "anarcho-evangelist" attitude, and provoking his colleagues by claiming, "If Narboni is the Engels of Cahiers, I am its Barrès." ${ }^{8}$ The differences between Delahaye and the rest of the journal did not go unnoticed by Cahiers' rivals, with Cinéthique relishing the opportunity to malign the "monument of modernist eclecticism, theoretical inconsistency and hippy senility."79 Delahaye stayed with the journal even after the break with Filipacchi, his part-time salary as editorial secretary being his only source of income at the time, but by October 1970 he was forced out against his will — a brief notice in that issue pointing to his "complete ideological and theoretical discord" with the journal's editorial line. ${ }^{80}$ Right up until his death in 2016, Delahaye remained bitter about the experience and spoke scathingly about the political evolution of Cahiers up to and after his departure. ${ }^{81}$

\section{The Dispute with Filipacchi}

As Cahiers radicalized, a clash with its owner was increasingly seen as inevitable. Relations had never been entirely smooth: while the Cahiers editors acceded to Filipacchi's demands to withdraw Godard's La Religieuse editorial in April 1966, they affirmed their autonomy six months later when Filipacchi accepted a lavish eight-page spread (and full-color front cover) advertising Chappaqua by the self-funded American filmmaker Conrad Rooks, an "experimental" feature remote from Cahiers' own tastes. The editors remained defiant: in the same October 1966 issue, the film was ridiculed in a brief notice incorporated into Cahiers' coverage of that year's Venice festival. Written by Narboni but published anonymously, ${ }^{82}$ the review labeled Chappaqua "the Cleopatra and West Side Story of beatnik cinema" and suggested that its merits could be tested by being screened

78 See De Baecque, Histoire d'une revue vol. II, p. 226. Maurice Barrès was a writer and right-wing nationalist in the late nineteenth and early twentieth centuries.

79 "Du bon usage de la valeur d'échange (les Cahiers du cinéma et le marxisme-léninisme)," p. 4 .

80 La Rédaction, "Informations," Cahiers du cinéma no. 224 (October 1970), p. 57.

81 See Interviews with Michel Delahaye, April 11, 2014 and May 1, 2014. Delahaye's writings for Cahiers are collected in Michel Delahaye, À la fortune du beau (Paris: Capricci, 2010). For more on his life, see Daniel Fairfax, "Farewell Michel Delahaye," Senses of Cinema no. 81 (December 2016), sensesofcinemacom/2016/feature-articles/farewell-michel-delahaye/ (accessed January 1, 2021). 82 Narboni admitted to his authorship of the article when interviewed, and it is of a piece with his writing style at the time. Interview with Jean Narboni, March 18, 2014. 
for the Red Guards. The only (ironic) words of praise in the review were for Conrad Rooks' exorbitant publicity strategy. ${ }^{83}$

Unable to bring their editorial independence into question, Filipacchi bit his tongue at this act of critical recalcitrance. Matters were different when it came to the journal's participation in the Henri Langlois defense campaign. With the journal's Champs-Elysées offices transformed into the movement's headquarters, the Cahiers editors racked up a significant phone bill from the international calls imploring foreign directors to withhold their permission for cinémathèque screenings, and Filipacchi wrote to Truffaut demanding that the Defense Committee reimburse the expenses. ${ }^{84}$ De Baecque reports, too, that 1969 saw a worsening of the journal's financial situation, losing 26,466 francs in the first nine months of the year. ${ }^{85}$ Conversely, the editors were increasingly frustrated at their association with the media tycoon. In "Cinéma/idéologie/critique," Comolli/Narboni dismissed the "utopia of parallelism" and accepted that their journal was inserted into the "economic system of capitalist publishing." ${ }^{86}$ But having to suffer barbed comments about their subordinate status to the Filipacchi group from Cinéthique and-more galling still-Jean-Luc Godard was difficult for the editors to abide. $^{87}$

Matters came to a head in October 1969. De Baecque gives a detailed account of Filipacchi's experience of reading issue no. 216, presumably drawn from a letter the publisher wrote to the journal's editors. ${ }^{88}$ For the present-day film scholar, the number in question contains a bounty of ground-breaking texts: “Cinéma/idéologie/critique," was accompanied by a translated installment of Eisenstein's Non-indifferent Nature (appearing in French for the first time), Raymond Bellour's analysis of the Bodega Bay sequence from The Birds, and a scintillating interview with Luc Moullet. ${ }^{89}$ Filipacchi, however, was infuriated at the conceptual obtuseness and political stridency of these texts, and his rage climaxed upon reading a review of La Sirène du Mississippi by Oudart, the language of which was particularly

83 [Anon.], “Chappaqua de Conrad Rooks (USA)," Cahiers du cinéma no. 183 (October 1966), pp. 30-31. A notice on p. 33 of this issue advised that "the unsigned review is collective."

84 The exchange can be found in the Fonds Comité de Défense de la Cinémathèque française in the Espace chercheurs de la Cinémathèque française, $\mathrm{CDCF}_{13}-\mathrm{B} 7$.

85 See de Baecque, Histoire d'une revue vol. II, p. 220.

86 Comolli/Narboni, "Cinéma/idéologie/critique," p. 11 [p. 251].

87 See Godard, "Un cinéaste comme les autres.”

88 See de Baecque, Histoire d'une revue vol. II, pp. 220-222.

89 See Luc Moullet, interviewed by Michel Delahaye and Jean Narboni, "Entretien avec Luc Moullet," Cahiers du cinéma no. 208 (January 1969), pp. 40-49, 56-62. 
impenetrable for those unversed in contemporary theory, as attested by passages such as:

Here, the return to the literality of the énoncé is no longer, as in La Voie lactée, the utopian guarantee of a 'true' reading delivered from the clutches of connotation: for the process of reading is reversed, resting on an énoncé whose literality (the return to the letter) is only ever a pause, a halt, an eclipse of meaning, a limit and a scansion of the cinematic text. ${ }^{90}$

Filipacchi called for a meeting with the editors on October 20, but proceedings were mired in a stalemate, and the following day Narboni and Comolli found themselves locked out of their offices, with a tongue-in-cheek press release put out by Filipacchi declaring that "the managers and the majority of shareholders of the monthly Cahiers du cinéma have decided on an indefinite strike" and demanding "the liberalization of the magazine which [...] has, in the hands of the intransigently totalitarian editors, become an obscure, indigestible publication from which all objectivity has been excluded."91 The Cahiers editors publicly responded by affirming their "intention to preserve the total liberty of action and critical spirit" of the journal. ${ }^{92} \mathrm{~A}$ second meeting, presided over by lawyer George Kiejman, sought to resolve the impasse: Filipacchi initially demanded a new, broad-based editorial team, and when the editors refused what they saw as a "committee of patronagesurveillance," ${ }^{\prime 93}$ he offered to sell his shares for the sum of 280,000 francs. The November issue appeared as usual, "in the interests of Cahiers and its readers," ${ }^{\prime 94}$ and showed no signs of a softening in Cahiers' line, but after that, publication was suspended; it would not resume until March 1970.

With this offer from Filipacchi on the table, the journal mobilized in a bid to achieve its financial independence. An op-ed article in Le Monde by Comolli and Narboni defended Cahiers as having always been "a review of opinion and criticism, making choices which, beyond their polemical appearance, proceed from a work of reflection on the cinema" while justifying its more recent turn towards the "new cinemas" outside of Hollywood as well as its concern for "research carried out in domains other than the cinema

90 Jean-Pierre Oudart, "Rêverie bouclée (La Sirène de Mississippi)," Cahiers du cinéma no. 216 (October 1969), pp. 51-52, here p. $5^{1 .}$

91 The press release is cited in full in De Baecque, Histoire d'une revue vol. II, p. 222.

92 [Anon.], "Conflit aux Cahiers du cinéma," Le Monde October 22, 1969.

93 As Comolli and Narboni dubbed his proposed structure. "Éditorial," Cahiers du cinéma no. 228 (March-April 1971), p. 5 .

94 As a notice published by Cahiers put it. See Cahiers du cinéma no. 217 (November 1969), p. 3. 
(Marxism, psychoanalysis and linguistics primarily)." They concluded that: "It does not appear possible to us to keep cinema (or any other aesthetic manifestation) sealed off or sheltered away from history and politics. Although transforming Cahiers into a political tribune has always been out of the question, we are unable to analyze the cinema without analyzing the mechanisms determining it, on both an economic level (production, distribution) and an ideological level (content, forms). ${ }^{\prime 95}$ Friends and sympathizers of the journal were exhorted to contribute capital, with Comolli, Narboni, Sylvie Pierre, Jean Riboud, Claude Berri, Pierre Braunberger, Pierre Cardin and even Costa-Gavras investing in the venture. By January 10, Le Monde reported that "an agreement has been reached between the editors of Cahiers du cinéma and their proprietor, M. Daniel Filipacchi," and the newspaper announced the reappearance of Cahiers under the same editorial team. ${ }^{6}$ Comolli recalls that Filipacchi was in fact "very upstanding about the matter, he did not insist on an exorbitant price." 97 The tycoon himself has a more amused recollection of the sale of Cahiers. ${ }^{9}$

In any case, with the handover settled, Cahiers now found itself, like the Cinémathèque, "free but poor." New offices were found at 39, rue Coquillère, near Les Halles in the $1^{\text {st }}$ arrondissement, considered better value than the Champs-Élysées area where they had previously been housed. An internal document on the "Reorganization and Re-purchasing" of Cahiers, now held in the Fonds Jacques Rivette, gives details on the administrative structure of the newly independent journal and precious insight into its day-to-day functioning. All administrative tasks previously exercised by Filipacchi's staff would now be undertaken by the editors themselves. Comolli and Narboni remained editors-in-chief on a salary of 1500 francs a month each, with Narboni responsible for subscriptions, stock and diffusion and Comolli overseeing publicity and promotion. Delahaye and Pierre remained on staff with a part-time salary of $65^{\circ}$ francs each, as the former was tasked with preparing the "Semaines des Cahiers" (until his sacking in October), and the

95 Jean-Louis Comolli and Jean Narboni, "Qu'est-ce que les Cahiers du cinéma?," Le Monde, November 2-3, 1969, p. 17.

96 [Anon.], "M. Daniel Filipacchi se retire des Cahiers du cinéma," Le Monde, January 10, 1970.

97 Comolli, "Yes, we were utopians (Part 1)."

98 In his 2012 memoir, Filipacchi speaks of the rupture with Cahiers in the following terms: "I had bought Cahiers to save it from collapse, at the request of Henri Langlois, but also because they defended the American cinema, notably thanks to François Truffaut. But soon Godard, Doniol-Valcroze and Truffaut abandoned Cahiers to make films, and a team of leftist madmen who had taken possession of the place became hysterical. The readers, already not very numerous, evaporated before my eyes. I lost the willpower." Daniel Filipacchi, Ceci n'est pas une autobiographie (Paris: Bernard Fixot, 2012), pp. 345-346. 
latter continued to administer the photothèque; they were joined by Aumont, who was given the position of editorial secretary at 1050 francs a month. In addition, freelance writers (pigistes) were paid at a rate of 30 centimes a line, with the total monthly ceiling established at 2500 francs (below the 400o-franc level under Filipacchi). A comité de rédaction comprising Rivette, Truffaut, Kast and Doniol-Valcroze was maintained as a supervisory body and was accompanied by a conseil de rédaction consisting of the most active contributors to the journal, which would hold weekly meetings where "all writers will participate, and all problems can be discussed."99

When the first issue of the financially autonomous Cahiers was released in March, an editorial notice exhorted readers to reinforce their support of the journal by taking out subscriptions (a doubling in the number of subscribers, from 4500 to 900o, was set as a target). It also insisted on the continued pertinence of the theoretical position established in the two installments of "Cinéma/idéologie/critique," one that was essentially rooted in Marxist aesthetics. The editors saw three key tasks for the journal: in addition to the work of "information and critical reflection" and the "circulation and diffusion of unknown and little-known films," they articulated the need for the elaboration of a critical theory that would be "founded on the Marxist science of historical materialism, and the principles of dialectical materialism." ${ }^{100}$ Rejecting the idea of a contradiction between the first task (information/criticism) and the third (theory), the editors tacitly took aim at their rivals Positif and Cinéthique: "abandoning to the formalist right (cf. no. 216) the eclectic exploitation of works regardless of whether they are subversive or not, we will also leave to the theologians of the "break" [coupure] the concern for fetishizing the handful of films that claim to have carried this out."101 In the early stages of this project, at least, the response from the journal's readership was broadly positive: the "Réponses aux lecteurs" column in July 1970 featured readers who, in the

99 “Cahiers du cinéma: Réorganisation et rachat," Fond Jacques Rivette, Espace chercheurs de la Cinémathèque française, dossier RIVETTE89-B21. A French franc in 1970 was worth roughly the same as a euro today (by way of comparison, the cover price of Cahiers was 6 francs then, and $€_{5.90}$ in 2020), although certain living expenses such as rent and eating out were considerably more affordable in 1970. Eisenschitz has spoken of the standard of living enjoyed by the Cahiers team at the time: "When he was with Newsreel, Robert Kramer said that nobody had any money but at the same time you didn't have any problems. It was the same: we went to restaurants, we never found ourselves in situations that were so difficult that we had to economize on restaurants, on movies (where we usually paid for tickets)." Interview with Bernard Eisenschitz, April 7, 2014. 100 "Éditorial," Cahiers du cinéma no. 218 (March 1970), pp. 3-4, here p. 4. 101 Ibid. 
words of one letter, declared themselves favorable to Cahiers' "pertinent, and even correct, interpretation and demarcation of the ideological vectors that confront each other in this field."102 In the March-April 1971 issue, the first anniversary of the journal's independence was toasted with the news that a moderate growth in readership had taken place. Subscriptions had risen from 4375 to 4540 , while off-the-shelf sales increased from 4766 to 5021 , to combine for a total circulation of nearly 10,000 copies. ${ }^{103}$ Certainly this was well short of the ambitious target set a year earlier, but the fact that Cahiers could be run on autonomous lines without losing readership was an achievement in and of itself and represented an important level of stability that could be built upon. As the journal's political line hardened between 1971 and 1973, however, its readership consequently suffered a dramatic collapse.

\section{Works Cited}

[Anon.], "Chappaqua de Conrad Rooks (USA)," Cahiers du cinéma no. 183 (October 1966), pp. 30-31.

—, "Conflit aux Cahiers du cinéma," Le Monde October 22, 1969.

—, "M. Daniel Filipacchi se retire des Cahiers du cinéma," Le Monde, January 10, 1970. Jacques Aumont, "Voir la nuit (La Religieuse)," Cahiers du cinéma 194 (October 1967), pp. $64-65$.

—, "Le Cahier des lecteurs," Cahiers du cinéma no. 205 (October 1968), p. 10.

—, "Lettres," Cahiers du cinéma no. 234-235 (December 1971-January-February 1972), pp. 101-102.

—, interviewed by Nicole Vulser, "Jacques Aumont, le cinéma né sous X," Le Monde, September 29, 2003.

—, interviewed by Patrice Blouin and Jean-Marc Lalanne, "Le gai savoir," Les Inrockuptibles, April 27, 2005, pp. 36-38.

Antoine de Baecque, Les Cahiers du cinéma: histoire d'une revue vol. II: Cinéma, tours détours 1959-1981 (Paris: Cahiers du cinéma, 1991).

102 Pierre Baudry, "Réponses aux lecteurs," Cahiers du cinéma no. 222 (July 1970), pp. 53-54, here p. 53 .

103 "Éditorial," Cahiers du cinéma no. 228 p. 5. The editors took no small pleasure in proving wrong those who "doubted that we could, by our own means, by taking over the running of the journal ourselves, and without any 'commercial' concessions, continue to put it out under normal conditions." Indeed, ten issues had been published in the twelve months up to the editorial, each with substantially more text than the average issue in the Filipacchi years. 
Pierre Baudry, "Réponses aux lecteurs," Cahiers du cinéma no. 222 (July 1970), pp. 53-54.

Jacques Bontemps, "Diligence des Straub," Trafic no. 9 (Winter 1994), pp. 76-85. [Cahiers du cinéma], "Éditorial," Cahiers du cinéma no. 145 (July 1963), p. 1.

_-, "L’Affaire Langlois: 2. Conférence de presse," Cahiers du cinéma no. 199 (March 1968), pp. 34-44.

—, "Éditorial," Cahiers du cinéma 200-201 (April-May 1968), p. 5.

—, "Vers un livre blanc du cinéma français," Cahiers du cinéma no. 200-201 (AprilMay 1968), pp. 73-93.

—, "Le retour de Langlois," Cahiers du cinéma no. 202 (June-July 1968), p. 68.

—, "Éditorial," Cahiers du cinéma no. 203 (August 1968), p. 5.

—_, "Les états-généraux du cinéma," Cahiers du cinéma no. 203 (August 1968), pp. 23-46.

—, "Éditorial," Cahiers du cinéma no. 218 (March 1970), pp. 3-4.

—, "Informations," Cahiers du cinéma no. 224 (October 1970), p. 57.

—, "Éditorial," Cahiers du cinéma no. 228 (March-April 1971), p. 5.

[Cinéthique], "Du bon usage de la valeur d'échange (Les Cahiers du cinéma et le marxisme-léninisme), Cinéthique no. 6 (January-February 1970), pp. 1-12.

Jean-Louis Comolli, "Une semaine comme une autre," Cahiers du cinéma no. 178 (May 1966), p. 66.

—, "L'Affaire Langlois: 1. Historique et bilan," Cahiers du cinéma no. 199 (March 1968), pp. 32-33.

—, "Les berets verts," Cahiers du cinéma no. 215 (September 1969), p. 65.

—, Cinéma contre spectacle (Lagrasse: Verdier, 2009). Translated as Cinema against Spectacle: Technique and Ideology Revisited, trans. and ed. Daniel Fairfax (Amsterdam: Amsterdam University Press, 2015).

—, interviewed by Daniel Fairfax, “'Yes, we were utopians; in a way, I still am...': An Interview with Jean-Louis Comolli (Part 1)," Senses of Cinema no. 62 (April 2012), sensesofcinema.com/2012/feature-articles/yes-we-were-utopians-in-a-way-istill-am-an-interview-with-jean-louis-comolli-part-1/ (accessed January 1, 2021).

-, Corps et cadre: Cinéma, éthique, politique (Lagrasse: Verdier, 2012).

— and Jacques Kebadian, Les fantômes de Mai 68 (Crisnée: Yellow Now, 2018).

— and Jean Narboni, "Cinéma/idéologie/critique," Cahiers du cinéma no. 216 (October 1969), pp. 11-15. Translated as “Cinema/Ideology/Criticism," trans. Daniel Fairfax, in Jean-Louis Comolli, Cinema against Spectacle: Technique and Ideology Revisited (Amsterdam: Amsterdam University Press, 2015), pp. 251-259.

— and Jean Narboni, “Qu'est-ce que les Cahiers du cinéma?," Le Monde, November 2-3, 1969, p. 17 .

Peter Cowie, Revolution!: The Explosion of World Cinema in the Sixties (New York: Faber and Faber, 2004). 
Serge Daney, "Un rien sur fond de musique douce (Family Jewels)," Cahiers du cinéma no. 175 (February 1966), pp. 36-37.

—, "Welles au pouvoir (Falstaff)," Cahiers du cinéma no. 181 (August 1966), pp. 26-28.

—, "Le pouvoir en miettes (La Prise du pouvoir par Louis XIV)," Cahiers du cinéma no. 186 (January 1967), pp. 64-65.

—, "La dé-faite (Hurry Sundown)," Cahiers du cinéma no. 196 (December 1967), pp. 63-64.

—, interviewed by Bill Krohn, "Les Cahiers du cinéma 1968-1977: Entretien avec Serge Daney par Bill Krohn," in Daney, La Maison cinéma et le monde vol. I: Les temps des Cahiers 1962-1981 (Paris: P.O.L., 2001, pp. 17-31. Translated as T.L. French [Bill Krohn], "Les Cahiers du Cinéma 1968-1977: Interview with Serge Daney," The Thousand Eyes no. 2 (1977), pp. 18-32.

—, La Rampe (Paris: Cahiers du cinéma, 1983).

—, Persévérance (Paris: P.O.L., 1993). Translated as Postcards from the Cinema, trans. Paul Douglas Grant (Oxford: Berg, 2007).

Guy Debord, La Société du spectacle (Paris: Buchet/Chastel, 1967). Translated as The Society of the Spectacle, trans. Donald Nicholson-Smith (New York: Zone Books, 1995).

Michel Delahaye, "Fin d'un festival: Cannes," Cahiers du cinéma no. 203 (August 1968), pp. 26-27.

—, À la fortune du beau (Paris: Capricci, 2010).

Jacques Doniol-Valcroze, "La ligne générale," Cahiers du cinéma no. 160 (November 1964), p. 7 .

Bernard Eisenschitz, "Les trois derniers films de Mario Bava," Midi-minuitfantastique no. 8 (January 1964), pp. 62-63.

—, "Lettre d'Italie," Midi-minuit fantastique no. 9 (July 1964), pp. 40-42.

—, "Entretien avec Edgar G. Ulmer" (with Jean-Claude Romer), Midi-minuit fantastique no. 13 (November 1965), pp. 1-14.

—, "Cannes 65," Midi-minuit fantastique no. 13 (November 1965), pp. 37-50.

_ , "Lettre d'Italie," Midi-minuit fantastique no. 13 (November 1965), pp. 55-58.

_., “Joseph Losey sur “Accident,"” Cahiers du cinéma no. 184 (November 1966), pp. 12-13.

—, Bogart (Paris: Losfeld, 1967).

—, "Lubitsch," L’Anthologie du cinéma no. 23 (March 1967).

—, "Abraham Polonsky par lui même," Positif no. 84 (May 1967), pp. 7-18.

_ , "Fairbanks," L'Anthologie du cinéma no. 59 (December 1969).

- interviewed by Fernando Ganzo, "A French Roman. A Story about the Influence of Soviet Avant-Garde on Cahiers du Cinéma and the Later Rediscovery of Nicholas Ray: An Interview with Bernard Eisenschitz," Cinema Comparat/ive Cinema no. 2 (Spring 2013), pp. 18-28. 
—, Bertrand Tavernier and Chris Wicking, "Corman parle," Positif no. 59 (March 1964), pp. 15-28.

—, Bernard Cohn and T. Perez-Turrent, "Pesaro 1967," Positifno. 88 (October 1967), pp. 20-26.

Daniel Fairfax, "Farewell Michel Delahaye," Senses of Cinema no. 81 (December 2016), sensesofcinemacom/2016/feature-articles/farewell-michel-delahaye/ (accessed January 1, 2021).

Daniel Filipacchi, Ceci n'est pas une autobiographie (Paris: Bernard Fixot, 2012).

Jean-Luc Godard, “Lettre au Ministre de 'Kultur," Le Nouvel Observateur, April 6, 1966. Repr. in Cahiers du cinéma no. 177 (April 1966), pp. 8-9. Translated as "Letter to the Minister of 'Kultur," in idem., Godard on Godard, trans. and ed. Tom Milne (New York: Da Capo Press, 1972), pp. 237-238.

— (unsigned), "La guerre est commencée," Cahiers du cinéma no. 177 (April 1966), unpublished version.

—, interviewed by J.-P.C. and G.L., "Un cinéaste comme les autres," Cinéthique no. 1 (c. January 1969), pp. 8-12.

Paul Grant, Cinéma Militant: Political Filmmaking \& May 1968 (New York: Wallflower Press, 2016).

Sylvia Harvey, May '68 and Film Culture (London: BFI, 1980).

Pierre Kast, "A Farewell to the Movies," Cahiers du cinéma no. 200-201 (AprilMay 1968), pp. 13-18.

Sébastien Layerle, Caméras en lutte en Mai 68: "Par ailleurs le cinéma est une arme...” (Paris: Nouveau Monde, 2008).

V.I. Lenin, “The State: A Lecture Delivered at the Sverdlov University, July 11, 1919," The Collected Works of V.I. Lenin vol. XXIX (Moscow: Progress Publishers, 1976), pp. 470-488.

Colin MacCabe, Godard: A Portrait of the Artist at Seventy (New York: Farrar, Straus and Giroux, 2003).

Laurent Mannoni, Histoire de la Cinémathèque française (Paris: Gallimard, 2006). Luc Moullet, interviewed by Michel Delahaye and Jean Narboni, "Entretien avec Luc Moullet," Cahiers du cinéma no. 208 (January 1969), pp. 40-49, 56-62.

Michel Mourlet, "Apologie de la violence," Cahiers du cinéma no. 107 (May 196o), pp. 24-27.

-, Sur un art ignoré: La mise en scène comme langage (Paris: Ramsay, 2008).

Jean Narboni, "Le Cahier des lecteurs," Cahiers du cinéma no. 208 (January 1969), p. 5.

—, "L'Armée des ombres," Cahiers du cinéma no. 216 (October 1969), p. 63.

Jean-Pierre Oudart, "Rêverie bouclée," Cahiers du cinéma no. 216 (October 1969), pp. $5^{1-52}$.

Sylvie Pierre, "L'ordre et l'ordinateur (Les Sans-espoir)," Cahiers du cinéma no. 187 (February 1967), pp. 66-68. 
—, "Une œuvre de salut public (Le Père Noël a les yeux bleus)," Cahiers du cinéma no. 188 (March 1967), p. 59.

—, "Poétique et politique (Oz fusis)," Cahiers du cinéma no. 190 (May 1967), p. 66.

—, "Le regard brûlant du conteur (La chasse au lion à l'arc)," Cahiers du cinéma no. 192 (July-August 1967), pp. 65-66.

—, "Le considérable talent de G.W. Pabst," Cahiers du cinéma no. 193 (September 1967), pp. 42-47.

—, interviewed by Bill Krohn, "Interview with Sylvie Pierre," Senses of Cinema no. 23 (December 2002), sensesofcinema.com/2002/feature-articles/pierre/ (accessed January 1, 2021).

La Rédaction, "Venise malgré tout," Cahiers du cinéma no. 206 (November 1968), pp. 23-24.

—, interviewed by Jacques Aumont, Jean-Louis Comolli, Jean Narboni and Sylvie Pierre, "Le temps déborde: Entretien avec Jacques Rivette," Cahiers du cinéma no. 204 (September 1968), pp. 6-21. Translated as "Time Overflowing," trans. Amy Gateff, in Jonathan Rosenbaum (ed.), Rivette: Texts and Interviews (London: BFI, 1977), pp. 9-38.

Glauber Rocha, interviewed by Michel Delahaye, Pierre Kast and Jean Narboni, "Entretien avec Glauber Rocha," Cahiers du cinéma no. 214 (July-August 1969), pp. $23-40$.

Louis Skorecki, Dialogues avec Daney (Paris: PUF, 2007).

[Visages du cinéma], "Éditorial," Visages du cinéma no. 1 (c. 1962), p. 2. 
